\title{
ORGANIC PRODUCTION OF RED WINE GRAPES UNDER PLASTIC COVER IN SUBTROPICAL REGION OF BRAZIL
}

\author{
Produção orgânica de uvas para vinho tinto sob cobertura \\ plástica em região subtropical do Brasil
}

\author{
Renato Vasconcelos Botelho ${ }^{1}$, Alexandre Pozzobom Pavanello ${ }^{3}$, Erasmo José Paoli Pires ${ }^{4}$, \\ Maurilo Monteiro Terra ${ }^{4}$, Marcelo Marques Lopes Müller ${ }^{2}$
}

\begin{abstract}
A trial was carried out aiming to evaluate the development and yield of red wine grapevines under plastic cover in an organic production system in Guarapuava, the Central-Southern region of Paraná State, Brazil. The experimental design was in a randomized blocks, in a $5 \times 2$ factorial arrangement (cultivars x rootstocks), with five red wine vine cultivars (Merlot, Malbec, Carbenet Sauvignon, Ives and Early Isabella) and two rootstocks (Paulsen 1103 e VR 043-43). The grafted grapevines were planted in September of 2005 and the evaluations carried out for the three first productive cycles $(2006 / 2007,2007 / 2008,2008 / 2009)$. The following variables were evaluated: phenological growth stages, number of clusters, average cluster weight, total yield, total soluble solids content and fresh weight of pruning material. The cultivation of wine grapevines in an organic system under plastic cover demonstrated viability, inhibiting the incidence of diseases and reducing the needs of control. The most limiting factor was the damage caused by wasps and bees that decreased cluster harvest. Despite this problem, between tested grapevine cultivars, the Early Isabella was the most productive in all years, while Malbec was also outstanding in the first cycle. VR 043-43 hybrid could be a suitable rootstock for red wine production in areas infested by 'Perola da Terra' scale insects (Eurhizococcus brasiliensis).
\end{abstract}

Index terms: Vitis spp., grapevines, 'VR 043-43', agroecology.

\section{RESUMO}

Um experimento foi conduzido com o objetivo de avaliar o desenvolvimento e produtividade de uvas para vinho tinto sob cobertura plástica, em sistema orgânico, em Guarapuava, região centro-sul do estado do Paraná, Brasil. O delineamento experimental foi em blocos casualizados, em esquema fatorial $5 \times 2$ (cultivares $\mathrm{x}$ porta-enxertos), com cinco cultivares de vinho tinto (Merlot, Malbec, Cabernet Sauvignon, Bordô e Isabel Precoce) e dois porta-enxertos (Paulsen 1103e VR 043-43). As videiras enxertadas foram plantadas em setembro de 2005 e as avaliações foram conduzidas nos três primeiros ciclos produtivos (2006/2007, 2007/2008, 2009/ 2009). Foram avaliadas as seguintes variáveis: estádios fenológicos, número de cachos, massa média dos cachos, produtividade, teor de sólidos solúveis totais e massa fresca do material de poda. O cultivo de videiras para vinificação em sistema orgânico sob cobertura plástica demonstrou ser viável, inibindo a incidência de doenças e reduzindo a necessidade de controle. $\mathrm{O}$ fator mais limitante foi o ataque de vespas e abelhas que severamente reduziram a colheita de cachos. Apesar desse problema, entre as cultivares de videira testadas, a Isabel Precoce foi a mais produtiva em todos os anos, enquanto a 'Malbec' foi também superior no primeiro ciclo. O híbrido 'VR 043-43' poderia ser um porta-enxerto adequado para a produção de uvas para vinho tinto em áreas infestadas com pérolada-terra (Eurhizococcus brasiliensis).

Termos para indexação: Vitis spp., videiras, VR 043-43, agroecologia.

(Received in october 1, 2010 and approved in june 27, 2011)

\section{INTRODUCTION}

Roughly half of all grapes harvested in Brazil are destined for wine, juice and derivatives. The rest is for fresh consumption. In 2009, the domestic production volume reached 1.345 million tons. In Paraná State viticulture is an important activity with production concentrated mostly on the northern region, attaining 102,080 tons (ANUÁRIO BRASILEIRO DE FRUTICULTURA, 2010).
Conventional agriculture is characterized by monoculture, intensive soil and irrigation use and chemical control of pests and diseases; and has been responsible for notable environmental impacts. The need to increase productive sustainability and the pressure of consumers groups has forced the reevaluation of such models of conventional production (FADINI, LOUSADA, 2001). Following this concept, the use of plastic cover represents an alternative for grape production, especially in warm and

\footnotetext{
'Universidade Estadual do Centro-Oeste/Unicentro - Departamento de Agronomia - Rua Simeão Varella de Sá - n. 03 - $85040-080$ - Guarapuava - PR Brasil-rbotelho@unicentro.br

Universidade Estadual do Centro-Oeste/Unicentro - Departamento de Agronomia - Guarapuava - PR - Brasi

${ }^{3}$ Universidade Estadual do Centro-Oeste/Unicentro - Acadêmico do Curso de Agronomia - Guarapuava - PR - Brasil

${ }^{4}$ Instituto Agronômico de Campinas/IAC - Campinas - SP - Brasil
}

Ciênc. agrotec., Lavras, v. 35, n. 6, p. 1186-1195, nov./dez., 2011 
humid climates, because this system could avoid the wetting of upper plant parts and, consequently, decrease pathogenic fungus, allowing the reduction or elimination of chemical fungicides (GENTA et al., 2010).

Chavarria et al. (2007) reported that during maturation of 'Moscato Gallo' grapes, there was a decrease of decay incidence between 57.6 and $84.5 \%$ due to plastic covers. In unprotected plots it was necessary to carry out 17 sprays with fungicides compared to only two applications in plastic covered plants.

For 'Jingyou' grapes the vineyard covered with plastic film increased the cluster numbers, berry weight and reduced the incidence of Botrytis. The berries of covered plants attained higher sugars and phenolic compost content and lower malic acid content. In the wine tasting survey, the covered plots presented the highest score (MING et al., 1998).

Additionally, the plastic cover presents other important advantages such as: plant protection against hailing and chilling temperatures in early spring, best fruit quality with higher soluble solids content and lower total trititable acidity, and; longer harvest period, for best selling prices (SHIEDECK et al., 1999; TAGLIARI, 2003).

Schiedeck et al. (1999) verified in 'Niagara Rosada' table grapes that protected cultivation allowed pruning 21 days earlier and, consequently, advanced harvest 23 days, which represented prices fivefold times higher compared to the regular growth season in the southern Brazilian. Nevertheless, according to Chavarria et al. (2010), due to the reduction of photosynthetically active radiation, there was a delay in sugar accumulation, and, consequently, a later harvest compared to unprotected cultivation.

Another aspect of sustainable viticulture is the use of pest resistance. Some researchers have demonstrated that rootstocks derived from Vitis rotundifolia Michx were more resistant to Eurhizococcus brasiliensis, more commonly known in Brazil as Brazilian ground pearl (BOTTON, COLLETA, 2010). Beside this, according to Pommer et al. (1997), the $V$. vinifera $L$. and $V$. rotundifolia hybrids, such as 'VR 043-43' and 'VR 039-16', are practically immune to some nematodes such as Xiphinema index and have high resistance to Phylloxera. Nevertheless, there is a lack of information about their influence in grapevine development and production in Brazilian conditions.

In this context, this research aimed to study the viability of organic production of red wine grapevines grafted on two different rootstocks in vineyards under plastic cover in the Central-Southern region of Paraná State, Brazil.

\section{MATERIAL AND METHODS}

This trial was carried out in the experimental vineyard of The Federal University of the Central-Western Region (Unicentro), in Guarapuava, Paraná state, Brazil $\left(25^{\circ} 23^{\prime} 36^{\prime \prime} \mathrm{S}\right.$ and $51^{\circ} 27^{\prime} 19^{\prime \prime} \mathrm{W}, 1,120 \mathrm{~m}$ a.s.l.). This region has a Subtropical Highland Climate $(C f b)$, according to the Köppen classification. The soil is classified as Brown distroferric Latosol (EMBRAPA, 2006).

The grapevines were planted in September 2005, spaced at $1.5 \times 2.0 \mathrm{~m}$, trained in a unilateral cordon on a three-wire trellis with drip irrigation, and cultivated under an organic production system. The planted lines were covered with transparent plastic film (low-density polyethylene - LDPE), 150 microns thick.

Organic fertilization was preferentially adopted, using materials more easily found in the production region (animal manures, agricultural and agroindustry residues, green manures) in quantities previously estimated according to vines needs and diagnosis (plant and soil analysis). Other non-organic sources allowed in Organic Production systems were used in function of soil fertility and plant exigencies (CQFS-RS/SC, 2004), such as: rockdusts, lime and natural phosphates. For pest control, products such as: neem oil, chinaberry extract, bordeaux mixture, lime-sulfur, garlic extract and attractive traps were allowed. An average of seven sprays was done for pests control in each vegetative cycle.

The experimental design was in randomized blocks, in a $5 \times 2$ factorial arrangement (cultivars $x$ rootstocks), with five red wine vine cultivars (Merlot, Malbec, Carbenet Sauvignon, Ives and Early Isabella) and two rootstocks (Paulsen 1103 e VR 043-43), totalizing 10 treatments, with five replications and three-plant plots. Each experimental block was composed of one planted line.

During the three first production seasons, 2006/ 2007, 2007/2008 and 2008/2009, the following variables were evaluated:

1) Phenological growth stages: five canes per plant were previously identified for weekly evaluation of the phonological growth stages according to Lorenz et al. (1995).

2) Number of clusters: all clusters were counted in each experimental plot.

3) Average cluster weight: calculated for each experimental plot as a function of the number of clusters and total yield, expressed in grams.

4) Total yield: all clusters of each experimental plot were weighed in a precision balance and the total yield was calculated as a function of the planting density, expressed in kilograms per hectare.

5) Soluble solids content: after harvest, a sample of 100 berries per experimental plot was used for analysis 
with an automatic temperature compensation refractometer (CARVALHO et al., 1990).

6) Fresh weight of pruning material: the pruned canes in the end of the winter were weighed in a precision balance, and the results expressed in grams.

All data were analysed statistically using ANOVA and factorial analysis methods in the Sisvar 5.1 statistical package (FERREIRA, 2008). Meaningful comparisons were generated using Tukey's test (5\% level).

\section{RESULTS AND DISCUSSION}

The dates of the phenological growth stages are showed in Table 1. In general, the phenological growth stages varied a little between years, due to the differences in climatic conditions. The influence of rootstocks on the growth stages was not verified, but the American grapevines 'Ives' and 'Early Isabella' (V. labrusca L.) sprouted earlier and showed a shorter vegetative cycle than the Europeans grapevines (V. vinifera ) 'Merlot', 'Malbec' and 'Cabernet Sauvignon'.

Table 1 - Dates of phenological growth stages of different grapevine cultivars grafted on 'Paulsen 1103' and 'VR 04343" rootstocks (Guarapuava, Paraná State, Brazil, 2006/2009).

\begin{tabular}{|c|c|c|c|c|c|}
\hline Cultivars & Rootstocks & Budburst & Full flowering & Beginning of ripening & Harvest \\
\hline \multicolumn{6}{|c|}{$2006 / 2007$} \\
\hline Early Isabella & \multirow{5}{*}{ Paulsen 1103} & 09.28 & 11.09 & 12.15 & 01.26 \\
\hline Ives & & 09.14 & 11.18 & 12.22 & 01.26 \\
\hline Merlot & & 10.11 & 11.24 & 01.17 & 02.01 \\
\hline Malbec & & 10.05 & 11.24 & 01.10 & 02.01 \\
\hline C. Sauvignon & & 10.19 & 11.24 & 01.17 & 02.13 \\
\hline Early Isabella & \multirow{5}{*}{ VR 043-43 } & 09.28 & 11.09 & 12.22 & 01.26 \\
\hline Ives & & 09.14 & 11.18 & 01.10 & 01.26 \\
\hline Merlot & & 10.19 & 12.15 & 01.17 & 02.01 \\
\hline Malbec & & 10.11 & 11.24 & 01.17 & 02.01 \\
\hline C. Sauvignon & & 10.19 & 12.01 & 01.17 & 02.13 \\
\hline \multicolumn{6}{|c|}{$2007 / 2008$} \\
\hline Early Isabella & \multirow{5}{*}{ Paulsen 1103} & 09.21 & 10.25 & 12.28 & 02.01 \\
\hline Ives & & 09.21 & 11.01 & 12.28 & 01.24 \\
\hline Merlot & & 09.28 & 11.09 & 12.28 & 02.08 \\
\hline Malbec & & 10.05 & 11.01 & 12.28 & 02.12 \\
\hline C. Sauvignon & & 09.21 & 11.09 & 12.28 & 02.18 \\
\hline Early Isabella & \multirow{5}{*}{ VR 043-43 } & 09.21 & 10.25 & 12.20 & 02.01 \\
\hline Ives & & 09.21 & 11.01 & 02.28 & 01.24 \\
\hline Merlot & & 10.05 & 11.09 & 12.28 & 02.08 \\
\hline Malbec & & 09.21 & 11.01 & 12.28 & 02.12 \\
\hline C. Sauvignon & & 10.05 & 11.09 & 12.28 & 02.18 \\
\hline \multicolumn{6}{|c|}{$2008 / 2009$} \\
\hline Early Isabella & \multirow{5}{*}{ Paulsen 1103} & 09.18 & 10.29 & 12.11 & 02.03 \\
\hline Ives & & 09.26 & 10.29 & 12.11 & 01.28 \\
\hline Merlot & & 09.18 & 11.06 & 12.11 & 02.12 \\
\hline Malbec & & 09.18 & 11.06 & 12.11 & 02.12 \\
\hline C. Sauvignon & & 09.18 & 11.06 & 12.11 & 02.12 \\
\hline Early Isabella & \multirow{5}{*}{ VR 043-43 } & 09.18 & 10.29 & 12.04 & 02.03 \\
\hline Ives & & 09.26 & 11.06 & 12.11 & 01.28 \\
\hline Merlot & & 09.26 & 11.06 & 12.11 & 02.12 \\
\hline Malbec & & 09.18 & 11.06 & 12.11 & 02.12 \\
\hline C. Sauvignon & & 09.18 & 11.06 & 12.11 & 02.12 \\
\hline
\end{tabular}

Ciênc. agrotec., Lavras, v. 35, n. 6, p. 1186-1195, nov./dez., 2011 
American grapevines reached budburst usually in the second half of September, while European grapevines achieved the same stage just in October in some years. Kuhl (2003) reported budburst in the beginning of September for 'Ives' and 'Isabella' grapevines in Bento Gonçalves, Rio Grande do Sul State.

The harvest of American grapevines usually happened during the second-half of January and the Europeans grapevines during February, very similar to reports from the mountain ranges of Rio Grande do Sul State, a traditional production region in Brazil (KUHN, 2003; RIZZON AND MIELE, 2002; RIZZON AND MIELE, 2003).

The non-use of synthetic insecticides increased the attack of wasps and bees on ripening berries, which was the most limiting factor on yield and fruit quality on organic production, forcing early harvest. The installation of honeybee feeders and the sowing of plant species with attractive flowers such as sunflower (Helianthus annuus L.) and buckwheat (Fagopyrum esculentum Moench) were not efficient in reducing insect attacks on berries. Detoni et al. (2007) also justified the very low yield of 'Cabernet Sauvignon' grapevines in organic systems due to the intense attack of bees.

The 'Early Isabella' grapevines showed the highest number of clusters in all evaluated years, producing from 17.0 to 21.8 clusters per plant, independent of the rootstock. In the 2006/2007 cycle, 'Malbec' grapevines (11.9 clusters) did not differ from 'Early Isabella' (17.0 clusters) (Table 2).

Table 2 - Number of clusters per plant of different grapevines cultivars grafted on 'Paulsen 1103' and 'VR 043-43' rootstocks (Guarapuava, Paraná State, Brazil, 2006/2009).

\begin{tabular}{|c|c|c|c|}
\hline \multirow[b]{2}{*}{ Grapevine cultivar } & \multicolumn{2}{|c|}{ Rootstocks } & \multirow[b]{2}{*}{ Mean } \\
\hline & Paulsen 1103 & VR 043-43 & \\
\hline \multicolumn{4}{|c|}{$2006 / 2007$} \\
\hline Early Isabella & 18.6 & 17.4 & $17.0 \mathrm{a}^{\mathrm{I}}$ \\
\hline Ives & 0.0 & 0.0 & $0.0 \mathrm{~d}$ \\
\hline Merlot & 4.6 & 0.0 & $2.3 \mathrm{~cd}$ \\
\hline Malbec & 11.3 & 12.5 & $11.9 \mathrm{ab}$ \\
\hline Cabernet Sauvignon & 9.3 & 6.4 & $7.8 \mathrm{bc}$ \\
\hline M ean & 8.8 & 7.2 & 7.8 \\
\hline C.V. (\%) & 63.10 & & \\
\hline Factors & Cultivar (Cv) & Rootstock (Rs) & $\mathrm{Cv} \times \mathrm{Rs}$ \\
\hline $\mathrm{F}$ & $20.713 * *$ & $1.101^{\mathrm{ns}}$ & $0.518^{\mathrm{ns}}$ \\
\hline \multicolumn{4}{|c|}{$2007 / 2008$} \\
\hline Early Isabella & 23.1 & 20.5 & $21.8 \mathrm{a}$ \\
\hline Ives & 12.9 & 13.4 & $13.1 \mathrm{~b}$ \\
\hline Merlot & 11.2 & 6.4 & $8.8 \mathrm{~b}$ \\
\hline Malbec & 7.9 & 12.1 & $10.0 \mathrm{~b}$ \\
\hline Cabernet Sauvignon & 15.7 & 11.7 & $13.7 \mathrm{~b}$ \\
\hline Mean & 12.8 & 14.1 & 13.5 \\
\hline $\mathrm{CV}(\%)$ & 37.66 & & \\
\hline Factors & Cultivar $(\mathrm{Cv})$ & Rootstock (Rs) & $\mathrm{Cv} \times \mathrm{Rs}$ \\
\hline $\mathrm{F}$ & $10.037 * *$ & $0.887^{\mathrm{ns}}$ & $1.320^{\mathrm{ns}}$ \\
\hline \multicolumn{4}{|c|}{$2008 / 2009$} \\
\hline Early Isabella & 23.1 & 22.8 & $22.9 a$ \\
\hline Ives & 13.0 & 11.1 & $12.0 \mathrm{~b}$ \\
\hline Merlot & 10.1 & 11.7 & $9.9 \mathrm{~b}$ \\
\hline Malbec & 10.7 & 9.8 & $11.2 \mathrm{~b}$ \\
\hline Cabernet Sauvignon & 12.9 & 14.6 & $13.7 \mathrm{~b}$ \\
\hline Mean & 13.9 & 14.0 & 13.9 \\
\hline $\mathrm{CV}(\%)$ & 33.46 & & \\
\hline Factors & Cultivar (Cv) & Rootstock (Rs) & $\mathrm{Cv} \times \mathrm{Rs}$ \\
\hline $\mathrm{F}$ & $9.781 * *$ & $0.001^{\mathrm{ns}}$ & $0.184^{\mathrm{ns}}$ \\
\hline
\end{tabular}

${ }^{1}$ Means in columns followed by the same letter are not significantly different at the $5 \%$ level using the means separation Tukey's test. $* *$ Significant at $0.01, \mathrm{~ns}=$ not statistically significant.

Ciênc. agrotec., Lavras, v. 35, n. 6, p. 1186-1195, nov./dez., 2011 
Detoni et al. (2007) reported an average of 21 clusters in 'Cabernet Sauvignon' grapevines grafted on 420-A rootstock, under plastic cover (Table 2).

There was not interaction between factors for the variable mean cluster weight. The cultivars Ives and Cabernet Sauvignon showed the lowest values of cluster weight, in the main cycles, independent of the rootstock (Table 3). The results were much lower than reported by other authors that verified mean cluster weight of $149.3 \mathrm{~g}$ for 'Cabernet Sauvignon' and 161.9g for 'Merlot' grapes (RIZZON and MIELE, 2002 AND RIZZON and MIELE, 2003). Detoni et al. (2007) also verified low mean cluster weight $(84 \mathrm{~g})$ in 'Cabernet Sauvignon' organic vineyards under plastic cover, suffering similar damage by honeybee attacks.

No interactions were verified for grapevine yields, but the effect of cultivars was significant. In the first year,

Table 3 - Mean cluster weight ( $\mathrm{g}$ ) of different grapevines cultivars grafted on 'Paulsen 1103' and 'VR 043-43' rootstocks (Guarapuava, Paraná State, Brazil, 2006/2009).

\begin{tabular}{|c|c|c|c|}
\hline \multirow[b]{2}{*}{ Grapevine Cultivar } & \multicolumn{2}{|c|}{ Rootstock } & \multirow[b]{2}{*}{ Mean } \\
\hline & Paulsen 1103 & VR 043-43 & \\
\hline \multicolumn{4}{|c|}{$2006 / 2007$} \\
\hline Early Isabella & 124.6 & 103.2 & $113.9 \mathrm{~b}$ \\
\hline Ives & - & - & - \\
\hline Merlot & 151.6 & - & $151.6 \mathrm{ab}$ \\
\hline Malbec & 208.9 & 229.2 & $219.0 \mathrm{a}$ \\
\hline Cabernet Sauvignon & 103.6 & 107.0 & $105.1 \mathrm{~b}$ \\
\hline Mean & 147.2 & 146.5 & 147.4 \\
\hline $\mathrm{CV}(\%)$ & 23.33 & & \\
\hline Factors & Cultivar $(\mathrm{Cv})$ & Rootstock (Rs) & $\mathrm{Cv} \times \mathrm{Rs}$ \\
\hline $\mathrm{F}$ & $108.42 * *$ & $1.153^{\mathrm{ns}}$ & $0.158^{\mathrm{ns}}$ \\
\hline \multicolumn{4}{|c|}{$2007 / 2008$} \\
\hline Early Isabella & 95.0 & 100.9 & $98.0 \mathrm{a}$ \\
\hline Ives & 37.5 & 38.0 & $37.4 \mathrm{bc}$ \\
\hline Merlot & 84.0 & 112.1 & $98.0 \mathrm{a}$ \\
\hline Malbec & 103.1 & 67.0 & $85.1 \mathrm{ab}$ \\
\hline Cabernet Sauvignon & 61.6 & 37.2 & $49.4 \mathrm{bc}$ \\
\hline Mean & 76.2 & 71.0 & 73.6 \\
\hline $\mathrm{CV}(\%)$ & 44.28 & & \\
\hline Factors & Cultivar $(\mathrm{Cv})$ & Rootstock (Rs) & $\mathrm{Cv} \times \mathrm{Rs}$ \\
\hline $\mathrm{F}$ & $7.513 * *$ & $0.319^{\mathrm{ns}}$ & $1.101^{\mathrm{ns}}$ \\
\hline \multicolumn{4}{|c|}{$2008 / 2009$} \\
\hline Early Isabella & 140.2 & 145.1 & $142.6 \mathrm{a}$ \\
\hline Ives & 68.7 & 70.4 & $69.5 \mathrm{~b}$ \\
\hline Merlot & 157.0 & 152.3 & $154.6 \mathrm{a}$ \\
\hline Malbec & 155.5 & 114.2 & $134.9 \mathrm{a}$ \\
\hline Cabernet Sauvignon & 88.3 & 79.0 & $83.6 \mathrm{~b}$ \\
\hline Mean & 121.9 & 112.2 & 117.0 \\
\hline $\mathrm{CV}(\%)$ & 30.72 & & \\
\hline Factors & Cultivar $(\mathrm{Cv})$ & Rootstock (Rs) & $\mathrm{Cv} \times \mathrm{Rs}$ \\
\hline $\mathrm{F}$ & $11.137 * *$ & $0.912^{\mathrm{ns}}$ & $0.660^{\mathrm{ns}}$ \\
\hline
\end{tabular}

${ }^{1}$ Means in columns followed by the same letter are not significantly different at the $5 \%$ level using the means separation Tukey's test. ** Significant at $0.01, \mathrm{~ns}=$ not statistically significant. 
'Early Isabella' and 'Malbec' grapevines were superior to the others, attaining 5,517.1 and 7,091.8 $\mathrm{kg} \mathrm{ha}^{-1}$. In the following two cycles, 'Early Isabella' showed higher yield, independent of the rootstock, reaching 5,718.0 and 8,900.3 $\mathrm{kg} \mathrm{ha}^{-1}$, in 2007/2008 and 2008/2009, respectively (Table 4). No significant fungus diseases were verified in the field over the three years evaluation, and the major yield limiting factor was wasps and honeybee attacks, but this was always lower in 'Early Isabella' grapes due to their early fruit maturation and harvest. Mota (2008) reported 6,892.0 $\mathrm{kg} \mathrm{ha}^{-1}$ in 'Cabernet Sauvignon' under plastic cover in Caxias do Sul, in the mountain ranges of Rio Grande do Sul State, while Detoni et al. (2007) verified $4.000 \mathrm{~kg} \mathrm{ha}^{-1}$ in Toledo, Western region of Paraná State.

For the variable total soluble solids content, there was interaction between factors on the first and third cycles,

Table 4 - Yield ( $\left.\mathrm{kg} \mathrm{ha}^{-1}\right)$ of different grapevines cultivars grafted on 'Paulsen 1103' and 'VR 043-43' rootstocks (Guarapuava, Paraná State, Brazil, 2006/2009).

\begin{tabular}{|c|c|c|c|}
\hline \multirow[b]{2}{*}{ Cultivars } & \multicolumn{2}{|c|}{ Rootstocks } & \multirow[b]{2}{*}{ Mean } \\
\hline & Paulsen 1103 & VR 043-43 & \\
\hline \multicolumn{4}{|c|}{$2006 / 2007$} \\
\hline Early Isabella & $6,288.0$ & $4,746.2$ & $5,517.1 \mathrm{ab}^{1}$ \\
\hline Ives & 0.0 & 0.0 & $0.0 \mathrm{c}$ \\
\hline Merlot & $1,998.6$ & 0.0 & $999.3 \mathrm{c}$ \\
\hline Malbec & $6,568.4$ & $7,615.2$ & $7,091.8 \mathrm{a}$ \\
\hline Cabernet Sauvignon & $2,579.6$ & $2,056.2$ & $2,317.9 \mathrm{bc}$ \\
\hline Mean & $3,486.9$ & $2,883.5$ & $3,185.2$ \\
\hline $\mathrm{CV}(\%)$ & 87.98 & & \\
\hline Factor & Cultivar (Cv) & Rootstock (Rs) & $\mathrm{Cv} \times \mathrm{Rs}$ \\
\hline $\mathrm{F}$ & $11.580^{* *}$ & $0.580^{\mathrm{ns}}$ & $0.471^{\mathrm{ns}}$ \\
\hline \multicolumn{4}{|c|}{$2007 / 2008$} \\
\hline Early Isabella & $5,798.9$ & $5,637.4$ & $5,718.0 \mathrm{a}$ \\
\hline Yves & $1,382.5$ & $1,674.5$ & $1,528.5 \mathrm{~b}$ \\
\hline Merlot & $2,564.1$ & $1,665.1$ & $2,114.6 \mathrm{~b}$ \\
\hline Malbec & $2,192.3$ & $2,222.3$ & $2,207.3 \mathrm{~b}$ \\
\hline Cabernet Sauvignon & $2,505.4$ & $1,306.1$ & $1,905.7 \mathrm{~b}$ \\
\hline Mean & $2,888.6$ & $2,501.1$ & $2,694.8$ \\
\hline $\mathrm{CV}(\%)$ & 46,02 & & \\
\hline Factors & Cultivar $(\mathrm{Cv})$ & Rootstock (Rs) & $\mathrm{Cv} \times \mathrm{Rs}$ \\
\hline $\mathrm{F}$ & $19.013^{* *}$ & $1.221^{\mathrm{ns}}$ & $0.653^{\mathrm{ns}}$ \\
\hline \multicolumn{4}{|c|}{$2008 / 2009$} \\
\hline Early Isabella & $8,764.9$ & $9,035.6$ & $8,900.3 a$ \\
\hline Ives & $2,579.2$ & $2,407.4$ & $2,493.3 \mathrm{~b}$ \\
\hline Merlot & $4,155.4$ & $4,006.2$ & $4,080.8 \mathrm{~b}$ \\
\hline Malbec & $4,210.2$ & $3,649.7$ & $3,931.0 \mathrm{~b}$ \\
\hline Cabernet Sauvignon & $2,975.4$ & $3,133.4$ & $3,054.4 \mathrm{~b}$ \\
\hline Mean & $4,537.0$ & $4,446.5$ & $4,488.4$ \\
\hline $\mathrm{CV}(\%)$ & 52.86 & & \\
\hline Factors & Cultivar (Cv) & Rootstock (Rs) & $\mathrm{Cv} \times \mathrm{Rs}$ \\
\hline $\mathrm{F}$ & $11.522 * *$ & $0.018^{\mathrm{ns}}$ & $0.047^{\mathrm{ns}}$ \\
\hline
\end{tabular}

${ }^{1}$ Means in columns followed by the same letter are not significantly different at the 5\% level using the means separation Tukey's test. $* *$ Significant at $0.01, \mathrm{~ns}=$ not statistically significant. 
and only cultivar effect in the 2007/2008 cycle. Actually, some vine cultivars grafted on 'VR 043-43' rootstock, showed grapes with slightly lower total soluble solids content in some years. This effect was verified on grapevines _Cabernet Sauvignon' in 2006/2007 and 'Early Isabella', 'Ives' and 'Malbec' in 2008/ 2009 (Table 5). Alvarenga et al. (2002) also verified effect of rootstocks on total soluble content in 'Niagara Rosada' grapes, in Southern region of Minas Gerais State.

In relation to the fresh weight of pruning material, there was interaction between factors in the two first years and cultivar effect in the last cycle (Table 6). The 'Early
Isabella' grapevines showed the highest cane fresh weight in 2006/2007 when grafted on 'Paulsen 1103' rootstock, but did not differ from 'Malbec'. In 2007/2008, the grapevines 'Early Isabella' and 'Cabernet Sauvignon' showed the highest cane weight, independent of the rootstock. Nevertheless, 'Malbec' grapevines were also outstanding when grafted on 'Paulsen 1103', while cv. Ives presented higher pruning material weight when grafted on 'VR 04343'rootstock. In 2008/2009, 'Early Isabella' and 'Cabernet Sauvignon' grapevines showed superior cane weight, independently of the rootstock (Table 6).

Table 5 - Total soluble solids content (\%) of different grape cultivars grafted on 'Paulsen 1103' and 'VR 043-43' rootstocks (Guarapuava, Paraná State, Brazil, 2006/2009).

\begin{tabular}{|c|c|c|c|}
\hline \multirow[b]{2}{*}{ Cultivars } & \multicolumn{2}{|c|}{ Rootstock } & \multirow[b]{2}{*}{ Mean } \\
\hline & Paulsen 1103 & VR 043-43 & \\
\hline \multicolumn{4}{|c|}{$2006 / 2007$} \\
\hline Early Isabella & $16.7 \mathrm{ab} \mathrm{A}^{1}$ & $17.5 \mathrm{a} \mathrm{A}$ & 17.1 \\
\hline Ives & - & - & - \\
\hline Merlot & $17.6 \mathrm{~b}$ & - & 17.6 \\
\hline Malbec & $15.6 \mathrm{~b} \mathrm{~A}$ & 16.1a A & 15.9 \\
\hline Cabernet Sauvignon & $18.3 \mathrm{a} \quad \mathrm{A}$ & $16.4 \mathrm{a} \mathrm{B}$ & 17.3 \\
\hline Mean & 17.0 & 16.7 & 16.9 \\
\hline $\mathrm{CV}(\%)$ & 7.79 & & \\
\hline Factors & Cultivar (Cv) & Rootstock (PE) & $\mathrm{Cv} \times \mathrm{Rs}$ \\
\hline $\mathrm{F}$ & $664.3 * *$ & $195.1 * *$ & $185.2 * *$ \\
\hline \multicolumn{4}{|c|}{$2007 / 2008$} \\
\hline Early Isabella & 18.8 & 16.5 & $16.8 \mathrm{a}$ \\
\hline Ives & 13.8 & 13.5 & $13.6 \mathrm{~b}$ \\
\hline Merlot & 18.0 & 16.9 & $17.4 \mathrm{a}$ \\
\hline Malbec & 18.2 & 18.0 & $18.1 \mathrm{a}$ \\
\hline Cabernet Sauvignon & 18.8 & 18.0 & $18.4 \mathrm{a}$ \\
\hline Mean & 17.2 & 16.6 & 16.9 \\
\hline $\mathrm{CV}(\%)$ & 10.21 & & \\
\hline Factors & Cultivar (Cv) & Rootstock (Rs) & Cv x Rs \\
\hline $\mathrm{F}$ & $12.32 * *$ & 1.680 n.s. & 0.105 n.s. \\
\hline \multicolumn{4}{|c|}{$2008 / 2009$} \\
\hline Early Isabella & $17.8 \mathrm{a} \quad \mathrm{A}$ & $16.2 \mathrm{a} \mathrm{B}$ & 17.0 \\
\hline Ives & $14.4 \mathrm{cA}$ & $13.2 \mathrm{bB}$ & 13.8 \\
\hline Merlot & $16.4 \mathrm{ab} \mathrm{A}$ & $16.5 \mathrm{bA}$ & 16.4 \\
\hline Malbec & $17.7 \mathrm{a} \quad \mathrm{A}$ & $15.4 \mathrm{bB}$ & 16.6 \\
\hline Cabernet Sauvignon & $15.0 \mathrm{bcA}$ & $15.4 \mathrm{bA}$ & 15.2 \\
\hline Mean & 16.3 & 15.3 & 15.8 \\
\hline $\mathrm{CV}(\%)$ & 5.94 & & \\
\hline Factors & Cultivar (Cv) & Rootstock (Rs) & $\mathrm{Cv} \times \mathrm{Rs}$ \\
\hline $\mathrm{F}$ & $19.29 * *$ & $12.43 * *$ & $3.71 *$ \\
\hline
\end{tabular}

${ }^{1}$ In a column, means followed by the same letter (lower case) and in a row, means followed by the same letter (upper case) are not significantly different by Tukey's multiple range test $(\mathrm{P}=0.05)$. $*$ significant at $5 \%, * *=$ significant at $1 \%$, ns $=$ not statistically significant. 
Table 6 - Fresh weight of pruning material (g) of different grapevines cultivars grafted on 'Paulsen 1103' and 'VR 04343’ rootstocks (Guarapuava, Paraná State, Brazil, 2006/2009).

\begin{tabular}{|c|c|c|c|}
\hline \multirow[b]{2}{*}{ Cultivars } & \multicolumn{2}{|c|}{ Rootstocks } & \multirow[b]{2}{*}{ Mean } \\
\hline & Paulsen 1103 & VR 043-43 & \\
\hline \multicolumn{4}{|c|}{$2006 / 2007$} \\
\hline Early Isabella & $260.8 \mathrm{a} \quad \mathrm{A}$ & $106.6 \mathrm{a} \quad \mathrm{B}$ & 183.7 \\
\hline Ives & 0.7 с A & 12.1a A & 6.4 \\
\hline Merlot & $24.6 \mathrm{bc} \mathrm{A}$ & $79.6 \mathrm{a} A$ & 52.1 \\
\hline Malbec & 149.2ab A & $86.0 \mathrm{a} \mathrm{A}$ & 117.6 \\
\hline Cabernet Sauvignon & 24.6 bc A & $110.4 \mathrm{a} \mathrm{A}$ & 67.5 \\
\hline Mean & 92.0 & 78.9 & 85.5 \\
\hline $\mathrm{CV}(\%)$ & 94.34 & & \\
\hline Factors & Cultivar (Cv) & Rootstock (Rs) & $\mathrm{Cv} \times \mathrm{Rs}$ \\
\hline $\mathrm{F}$ & $7.06^{* *}$ & 0.326 n.s. & $3.707^{*}$ \\
\hline \multicolumn{4}{|c|}{$2007 / 2008$} \\
\hline Early Isabella & 1,455.1a A & $1,540.9 \mathrm{a} \mathrm{A}$ & $1,498.0$ \\
\hline Ives & $442.0 \mathrm{bB}$ & $964.2 \mathrm{bA}$ & 703.1 \\
\hline Merlot & $796.8 \mathrm{bA}$ & $478.6 \mathrm{bA}$ & 637.7 \\
\hline Malbec & 1,388.2a A & $964.6 \mathrm{bB}$ & $1,176.4$ \\
\hline Cabernet Sauvignon & $1,647.6 \mathrm{a} \mathrm{A}$ & $1,856.4 \mathrm{a} \mathrm{A}$ & $1,752.0$ \\
\hline Mean & $1,145.9$ & $1,160.9$ & $1,153.4$ \\
\hline C.V. $(\%)$ & 27.33 & & \\
\hline Factors & Cultivar $(\mathrm{Cv})$ & Rootstock (Rs) & $\mathrm{Cv} \times \mathrm{Rs}$ \\
\hline $\mathrm{F}$ & $23.81 * *$ & 0.028 n.s. & $3.79 *$ \\
\hline \multicolumn{4}{|c|}{$2008 / 2009$} \\
\hline Early Isabella & $1,321.8$ & $1,359.2$ & $1,340.5 \mathrm{a}$ \\
\hline Ives & 975.8 & 977.6 & $976.7 \mathrm{~b}$ \\
\hline Merlot & 679.6 & 801.0 & $740.3 \mathrm{~b}$ \\
\hline Malbec & 950.3 & 994.4 & $972.3 \mathrm{~b}$ \\
\hline Cabernet Sauvignon & $1,213.0$ & $1,481.6$ & $1,347.3 \mathrm{a}$ \\
\hline Mean & $1,028.1$ & $1,122.4$ & \\
\hline $\mathrm{CV}(\%)$ & 25.43 & & \\
\hline Factors & Cultivar $(\mathrm{Cv})$ & Rootstock (Rs) & $\mathrm{Cv} \times \mathrm{Rs}$ \\
\hline $\mathrm{F}$ & $9.261 * *$ & $1.487^{\mathrm{ns}}$ & $0.383^{\mathrm{ns}}$ \\
\hline
\end{tabular}

${ }^{1}$ In a column, means followed by the same letter (lower case) and in a row, means followed by the same letter (upper case) are not significantly different by Tukey's multiple range test $(\mathrm{P}=0.05) . *=$ significant at $5 \%,{ }^{*}=$ significant at $1 \%, \mathrm{~ns}=$ not statistically significant.

According to these results, the 'Early Isabella' and 'Cabernet Sauvignon' showed higher vegetative development throughout the cycles. The best results verified for vines grafted on 'Paulsen 1103' rootstock in the first and second year for 'Early Isabella' and 'Malbec', respectively, could be attributed to the difficulty of the grafting establishment of 'VR 043-43' rootstock, already reported by Botelho et al. (2009). In the third cycle (2008/ 2009), vines grafted on 'VR 043-43' already showed similar vegetative development of those grafted on 'Paulsen 1103'. According to this experiment, it seems that the organic production of red wine grapevines under plastic 
cover is possible in the predominant warm and humid conditions where this trial was carried out. The needs for disease control were reduced to only seven applications per cycle with products allowed in organic production, while Chavarria et al. (2007) reported 17 applications of synthetic fungicides for disease control in grapevines in similar climatic conditions in the mountain range of Rio Grande do Sul State. The most limiting factor for this production system was the attack of wasps and bees, which may be solved by future research, testing, for example, perforated plastic bags (COELHO et al., 2008).

According to this experiment, it seems that the organic production of red wine grapevines under plastic cover is possible in the predominant warm and humid conditions where this trial was carried out. The needs for disease control were reduced to only seven applications per cycle with products allowed in organic production, while Chavarria et al. (2007) reported 17 applications of synthetic fungicides for disease control in grapevines in similar climatic conditions in the mountain range of Rio Grande do Sul State. The most limiting factor for this production system was the attack of wasps and bees, which may be solved by future research, testing, for example, perforated plastic bags (COELHO et al., 2008).

Although 'VR 043-43' rootstock showed few disadvantages such as difficulties in grafting establishment and slightly lowering of soluble solids content, it could be recommended in areas infested by "Perola da Terra" scale (Eurhizococcus brasiliensis), considering that this rootstock showed similar cluster yield of grapevines grafted on 'Paulsen 1103', one of the most used rootstock in Southern of Brazil, for wine grapes.

\section{CONCLUSIONS}

The cultivation of red wine grapevines in an organic system under plastic cover is possible, inhibiting the incidence of diseases and reducing the needs for control. The most limiting factor was the attacks of wasps and bees that severely decreases cluster yield.

Among all tested grapevines, the cultivar Early Isabella was the most productive in all years, while 'Malbec' was also outstanding in the first cycle.

'VR 043-43' could be a suitable rootstock for red wine production in areas infested by "Perola da Terra" scale (Eurhizococcus brasiliensis) infestation.

\section{ACKNOWLEDGEMENTS}

To the Conselho Nacional de Desenvolvimento Científico e Tecnológico - CNPq for the financial support of this research.

\section{REFERENCES}

ALVARENGA, A.A. et al. Influência do porta-enxerto sobre o crescimento e produção da cultivar de videira Niágara Rosada (Vitis labrusca L. x Vitis vinifera L.), em condições de solo ácido. Ciência e Agrotecnologia, Lavras, Edição Especial, p.1459-1464, 2002.

\section{ANUÁRIO BRASILEIRO DE FRUTICULTURA. Santa Cruz do Sul: Editora Gazeta, 2010. 162p.}

BOTELHO, R.V. et al. Propagação da videira 'niagara rosada' (Vitis labrusca) enxertada sobre o porta-enxerto 'VR-043-43' (V. vinifera X V. rotundifolia). Scientia Agraria, Curitiba, v.10, n.5, p.359-364,2009.

BOTTON, M.; COLLETA, V.D. Avaliação da resistência de cultivares de Vitis rotundifolia à pérola-da-terra (Hemiptera: Margarodidae) na região sul do Brasil. Acta Scientiarum

Agronomy, Maringá, v.32, n.2, p.213-216, 2010

CARVALHO, C.R.L. et al. Análise química de alimentos. Campinas: ITAL, 1990. 121p.

CHAVARRIA, G. et al. Incidência de doenças e necessidade de controle em cultivo protegido de videira. Revista Brasileira de Fruticultura, Jaboticabal, v.29, n.3, p.477-482, 2007.

CHAVARRIA, G. et al. Maturação de uvas Moscato Giallo sob cultivo protegido. Revista Brasileira de Fruticultura, Jaboticabal, v.32, n.1, p.151-160, 2010.

COELHO, L. R. et al. Controle de pragas do pessegueiro através do ensacamento dos frutos. Ciência e Agrotecnologia, Lavras, v. 32, n.6, p.1743-1747, 2008.

DETONI, A.M.; CLEMENTE, E.; FORNARI, C.

Produtividade e qualidade da uva 'Cabernet Sauvignon' produzida sob cobertura de plástico em cultivo orgânico. Revista Brasileira de Fruticultura, Jaboticabal, v.29, n.3, p.530-534, 2007.

EMBRAPA. Centro Nacional de Pesquisa de Solos. Sistema brasileiro de classificação de solos. 2. ed. Rio de Janeiro, 2006. 306 p.

FADINI, M.A.M.; LOUSADA, J.N.C. Impactos ambientais da agricultura convencional. Informe Agropecuário, Belo Horizonte, v.22, n.213, p.24-29, 2001. 
FERREIRA, D. F. Sisvar: um programa para análises e ensino de estatística. Revista Symposium, Lavras, v.6, p.36-41, 2008.

GENTA, W. et al. Manejo de míldio no cultivo protegido de videira de mesa ' $B R S$ Clara' Pesquisa_Agropecuária Brasileira, Brasília, v.45, n.12, p.1388-1395 2010.

KUHN, G.B. (Ed.). Uvas americanas e híbridas para processamento em clima temperado. Bento Gonçalves: Embrapa uva e vinho, 2003. (Sistema de Produção, 2). Disponível em: http:// sistemasdeproducao.cnptia.embrapa.br/FontesHTML/ Uva/UvaAmericanaHibridaClimaTemperado/index.htm. Acessado em: 05 jun. 2010.

LORENZ, D. H. et al. Phenological growth stages of the grapevine (Vitis vinifera L. ssp. vinifera) - Codes and descriptions according to the extended BBCH scale. Australian Journal of Grape and Wine Research, v.1, p.100-103, 1995.

MING, Y. et al. Effects of plastic house on fruit setting and fruit quality of Jingyou grape. Journal International des Sciences de la Vigne et du Vin, Bordeaux, v.32, n.3, p.129-136, 1998.
MOTA, C. S. et al Comportamento vegetativo e produtivo de videiras 'Cabernet Sauvignon' cultivadas sob cobertura plástica. Revista Brasileira de

Fruticultura, Jaboticabal, v. 30, n. 1, p. 148-153, 2008.

POMMER, C.V. et al. Variedades de videira para o Estado de São Paulo. Campinas: Instituto Agronômico, 1997. 59p (Boletim técnico).

RIZZON, L.A.; MIELE, A. Avaliação da cv. Cabernet Sauvignon para elaboração de vinho tinto. Ciência e Tecnologia de Alimentos, Campinas, v.22, n.2, p.192-198, 2002.

RIZZON, L.A.; MIELE, A. Avaliação da cv. Merlot para elaboração de vinho tinto. Ciência e Tecnologia de Alimentos, Campinas, v.23, supl., p.156-161, 2003.

SCHIEDECK, G. et al. Maturação da uva Niagara Rosada cultivada em estufa de plástico e a céu aberto. Ciência Rural, Santa Maria, v.29, n.4, p.629633,1999 .

TAGLIARI, P.S. Potencial para produção de vinhos nas regiões mais altas de Santa Catarina. Agropecuária Catarinense, Florianópolis, v.16, n.2, p.26-33, 2003. 